\title{
ENTRE O PASSADO E O PRESENTE: \\ QUAIS AS PERSPECTIVAS DE EDUCAÇÃO PARA O FUTURO DOS \\ TRABALHADORES E TRABALHADORAS EMPOBRECIDOS EM TERRITÓRIOS DA AMAZÔNIA MARANHENSE?
}

Maria de Fatima Felix Rosar

\section{RESUMO}

$\mathrm{O}$ texto estabelece as relações historicamente construídas como resultado do desenvolvimento do capitalismo, desde o século XVII, em território da Amazônia Maranhense, em que a terra tem sido fator determinante para a produção da desigualdade econômica e social. Mostrando os impactos do processo de cercamento das terras, questiona a estrutura fundiária predominantemente contrária ao desenvolvimento das populações dos trabalhadores e trabalhadoras rurais. Destaca a terra como variável determinante no processo de transformação dessa realidade e a educação, com qualificação profissional das populações que habitam territórios rurais, como instrumentos determinantes para sua participação política e conquista dos seus direitos sociais e econômicos.

Palavras-chave: capitalismo, Amazônia Maranhense, trabalhadores rurais

\section{BETWEEN THE PAST AND THE PRESENT: WHAT ARE THE PROSPECTS OF EDUCATION FOR THE FUTURE OF WORKERS AND IMPOVERISHED WORKERS IN THE AMAZON TERRITORY IN THE MARANHÃO?}

\begin{abstract}
The text establishes the relationships built as a result of historical development of capitalism since the seventeenth century in the Amazon territory in the state of Maranhão, in which the land has been a decisive factor for the production of economic and social inequality. Showing the impacts of the process of fencing the land, it questions the agrarian structure which essentially hinders the development of rural workers. It also highlights the land as a determining variable in the process of transformation of this reality and education and professional qualification of people living in rural areas as an important tool for achieving political participation and ensuring their social and economic rights.

Keywords: capitalism, Amazonia of Maranhão, rural workers
\end{abstract}

\section{1- Introdução}

A história do Maranhão, entre o século XVII e o século XXI, mantém uma linha de continuidade que gera perplexidades e expectativas em relação ao momento em que esse "fio condutor" possa vir a ser rompido, caso se materialize uma mudança de qualidade no processo de seu desenvolvimento, em que tem prevalecido um caráter de elevado grau predatório, quer se tome a dimensão da natureza ou a dimensão humana, como aspectos desse desenvolvimento. 
O desenvolvimento do capitalismo no Maranhão adquiriu especificidades que compõem, na atualidade, um cenário que pode ser comparado a um grande painel de elementos correspondentes a diferentes formas de realização do processo de acumulação do capital e, também, da forma como se estabelecem as relações sociais de produção nesse contexto, em que se mesclam modos de realização do trabalho, em sua manifestação mais primitiva, com outros modos que expressam a incorporação de elevada complexidade tecnológica. O passado e o futuro se interpenetram, mas não se influenciam necessariamente, no sentido da superação do modo predatório como operam os donos do capital em relação à natureza e aos seres humanos.

No passado colonial, construiu-se um paradigma de sociedade cujos impactos reverberam até o presente, oportunizando ao mesmo tempo, a reprodução de bases materiais e de fundamentos ideológicos que constituem uma amálgama consistente e, à primeira vista, impossível de se diluir. Uma sociedade de base escravocrata, uma economia de subsistência para a maioria e de acumulação de dividendos e lucros para suas elites, por intermédio da atuação do Estado, definiu uma configuração socioeconômica e cultural que, tanto no passado como no presente, tem se expandido em períodos demarcados, historicamente, pelo predomínio de fatores exógenos, mediante investimento do grande capital nos setores de produção para a exportação, como é o caso dos grandes projetos Alcoa, Carajás, além da cultura da soja e, mais recentemente, do projeto de implantação de uma Refinaria de Petróleo.

É reconhecido na história do desenvolvimento do capitalismo seu caráter expansivo e cumulativo, que permite concentração de renda e também a degradação das condições de vida e da natureza, dado que, pelo seu modo de operação nos diversos setores de organização da sociedade, tem como finalidade realizar o circuito produção -circulação consumo e reprodução ampliada do capital. Isto significa que o capitalismo não tem como seu foco principal a condição humana e seu modo de viver, exceto no que se refere à formatação de hábitos que permitam expandir o consumo de seus produtos, nos quais prevalece a dimensão do valor e não de uso.

A mercadoria, e não os humanos, constitui a prioridade para o capitalismo, embora também resulte de sua expansão um conjunto de produtos que são notáveis, no que se refere ao desenvolvimento da ciência e da tecnologia. Entretanto, esses resultados, quando materializados, beneficiam de modo diferenciado as diferentes classes sociais e portanto, de modo muito mais restrito, os segmentos dos trabalhadores que, historicamente, foram empobrecidas nos territórios rurais do Brasil.

O presente texto concentra-se sobre essa realidade rural de um território maranhense que integra a Amazônia e no qual tem se produzido e reproduzido condições de vida e de trabalho muito precárias que constituem condicionalidades impeditivas ao processo de desenvolvimento justo e democrático dos municípios mais isolados e, nem por isso, menos explorados, do ponto de vista de suas riquezas naturais e da força de trabalho capturada para o trabalho em condições análogas a escravidão.

$\mathrm{Na}$ realidade, vivem esses segmentos de trabalhadores e trabalhadoras, quer seja no Maranhão, no Pará ou no Amazonas, como se fossem invisíveis e não tivessem sido eles os legítimos herdeiros de seus ancestrais que nasceram, cresceram e morreram, cultivando a terra e produzindo alimentos para as populações que habitam as cidades, embora também, no espaço urbano, esteja instalada a mesma forma de discriminação e de exploração que atinge os trabalhadores rurais empobrecidos em decorrência do modo de produção capitalista. 


\section{2- Elementos históricos, geográficos, econômicos e sociais do território}

O Território Rural Campos e Lagos, homologado pelo Governo Federal em 2008, situa-se na região da Baixada Maranhense, compreendendo 12 municípios: Arari, Cajari, Matinha, Olinda Nova do Maranhão, Palmeirândia, Pedro do Rosário, Penalva, São Bento, São João Batista, São Vicente Férrer, Viana, Vitória do Mearim.

Tabela 1 - Variação Populacional - Território 141 - Campos e Lagos - MA

\begin{tabular}{|l|c|c|c|c|c|}
\hline Município & $\begin{array}{c}\text { População } \\
2000\end{array}$ & $\begin{array}{c}\text { População } \\
2007\end{array}$ & $\begin{array}{c}\text { População } \\
2009\end{array}$ & $\begin{array}{c}\text { Variação } \\
\text { populacional } \\
2000-2007\end{array}$ & $\begin{array}{c}\text { Variação } \\
\text { populacional } \\
2007-2009\end{array}$ \\
\hline Arari & 26.366 & 27.673 & 28.787 & 4,96 & 4,02 \\
\hline Cajari & 13.405 & 12.753 & 13.170 & $-4,86$ & 3,2 \\
\hline Matinha & 19.231 & 20.396 & 21.204 & 6,06 & 3,96 \\
\hline $\begin{array}{l}\text { Olinda Nova do } \\
\text { Maranhão }\end{array}$ & 10.128 & 12.054 & 12.684 & 19,02 & 5,2 \\
\hline Palmeirândia & 17.264 & 18.074 & 18.772 & 4,69 & 3,84 \\
\hline Pedro do Rosário & 17.954 & 21.656 & 22.856 & 20,62 & 5,54 \\
\hline Penalva & 30.299 & 33.384 & 34.907 & 10,18 & 4,56 \\
\hline São Bento & 31.819 & 37.370 & 39.312 & 17,45 & 5,19 \\
\hline São João Batista & 18.917 & 18.065 & 18.570 & $-4,50$ & 2,7 \\
\hline São Vicente Ferrer & 18.406 & 19.647 & 20.463 & 6,74 & 4,15 \\
\hline Viana & 44.190 & 47.304 & 49.348 & & 4,05 \\
\hline Vitória do Mearim & 29.953 & 30.826 & 32.018 & 2,91 & \\
\hline Total do território & 277.932 & 299.202 & 312.091 & 7,65 & 3,86 \\
\hline
\end{tabular}

Fonte: IBGE Censo demográfico 2000/ contagem da população em 2007 e estimativa para 2009.

A homologação do território pelo Ministério do Desenvolvimento Agrário abriu algumas perspectivas de inclusão de sua população em programas e projetos do Governo Federal. A região da Baixada Maranhense detém indicadores da precariedade que se reproduz há muitas décadas, evidenciando problemas de ordem estrutural e de caráter conjuntural, dada a inexistência ou fragilidade das políticas de Estado na área da educação, saúde, infraestrutura, habitação e economia agropecuária.

Ainda que se localizem nesse território municípios muito antigos, criados ainda no século XVII ${ }^{1}$, como é o caso de Viana e São Bento, constata-se que elementos predominantes do paradigma colonial de desenvolvimento ainda hoje produzem impactos no presente, embora se alterem as características da economia de exploração de matérias primas e exportação, inerentes ao período mercantil capitalista do século XVI, para as características da economia de subsistência, no século XXI, no bojo de uma conjuntura em que ocorre o pleno desenvolvimento das práticas de financeirização da economia mundial.

A propósito dessa constatação de que existia um modo predominante de funcionamento da economia no Maranhão, Lacroix, ao estudar a Baixada Maranhense ${ }^{2}$ afirma:

O capitalismo nascente na Europa Ocidental, impulsionado pela Revolução industrial, não conseguiu desarticular as formas tradicionais de produção maranhense, que à época imperial, conservaram uma economia mercantil, determinante de funções e consumidora, além de uma economia natural, determinada, de subsistência natural no setor 
agrícola e industrial, com tecnologia rudimentar. Nem podia ter sido diferente, uma vez que 'o dinamismo nesse primeiro surto industrial na Inglaterra e na Europa Continental reforçou a conveniência de importar alimentos e matérias primas dos países atualmente subdesenvolvidos'. (LACROIX : 1982, p.18)

Desse modo, nessa região se materializa uma característica que não diz respeito apenas à economia do estado do Maranhão, mas que é própria do país no conjunto de suas regiões, qual seja, a existência de um processo de desenvolvimento que é desigual e diferenciado, o que implica em articulações entre segmentos avançados e menos avançados da economia como um todo, sendo perceptível o estabelecimento de "relações de produção capitalistas 'modernas' ao lado de outras 'atrasadas' não-capitalistas, mas completamente integradas ao mercado". ( MESQUITA, 2006, p.36)

Embora não se pretenda resgatar a história da economia da Baixada Maranhense, sabe-se que é indispensável tratar dos elementos básicos da configuração econômica da região, focando as questões fundamentais para a construção de perspectivas para mudanças de seu padrão de desenvolvimento, baseado nas potencialidades locais e para a sua expansão, a partir de um circuito de produção, comercialização e consumo que tenha como ponto de partida e de chegada a realidade local, beneficiando os trabalhadores e trabalhadoras e as populações urbanas de baixa renda dos municípios do TR Campos e Lagos.

Mesmo que a economia local tenha necessidade de se articular com setores do mercado interno da região e externos a ela e, até ao país, é visível que a defesa de um desenvolvimento territorial sustentável implica alcançar certo grau de autonomia, que somente pode ser atingido quando as populações que habitam o campo tiverem a posse da terra que cultivam, adicionando a esse processo de trabalho os conhecimentos construídos mediante a intersecção entre a teoria e a prática, além de obterem acesso a recursos financeiros, sem os quais permanecerão isoladas, excluídas e, portanto, marginalizadas do próprio processo de desenvolvimento do país, mesmo que estejam inseridas no mercado, na condição de produtoras e consumidoras.

A Baixada Maranhense começou a ser colonizada ainda no século XVII. A cidade de São Luís, capital do estado do Maranhão, foi fundada em 1612. A capitania secundária de Cumã, que posteriormente deu origem ao município de São Bento, tem documentos que revelam sua criação no ano de 1621.

Ao findar o período colonial, o Maranhão tinha duas escolas secundárias em São Luís e doze escolas de primeiras letras, sendo quatro dessas, na Baixada: Alcântara, São Bento, Guimarães e Viana. Em 1829, as aulas régias foram substituídas por vinte e quatro escolas públicas instaladas na província, inclusive oito em municípios da Baixada Maranhense. Em 1835, foram contabilizados 650 alunos matriculados nas escolas de primeiras letras, o que correspondia a $1 \%$ da população que era de 45.508 , sem contar com a população escrava que foi de aproximadamente 25.000 negros (LACROIX, 1982).

Em 2000, transcorridos dois séculos do período colonial, o Atlas do Desenvolvimento Humano registrou dados precários da realidade do TR Campos e Lagos na Baixada Maranhense, deixando nítida a tendência de abandono dessa população, por parte dos órgãos governamentais.

Tabela 2 - Indicadores sociais do Território dos Campos e Lagos

Revista HISTEDBR On-line, Campinas, número especial, p. 5-27, out2011 - ISSN: 1676-2584 


\begin{tabular}{|l|l|l|l|l|}
\hline Municípios & $\begin{array}{l}\text { Nível de } \\
\text { Pobreza }\end{array}$ & $\begin{array}{l}\text { Mortalidade } \\
\text { Infantil }\end{array}$ & $\begin{array}{l}\text { Analfabetismo } \\
\text { com + 15 anos }\end{array}$ & IDH \\
\hline Arari & 65,7 & 60,4 & 29,47 & 0,617 \\
\hline Cajari & 85,9 & 67,4 & 19,43 & 0,589 \\
\hline Matinha & 77,6 & 40 & 24,21 & 0,640 \\
\hline Olinda Nova Ma & 77,7 & 56,6 & 29,07 & 0,596 \\
\hline Palmeirândia & 84,0 & 67,4 & 32,48 & 0,569 \\
\hline Pedro do Rosário & 86,4 & 60,5 & 36,2 & 0,536 \\
\hline Penalva & 81,1 & 56,6 & 28,86 & 0,584 \\
\hline São Bento & 76,2 & 67,4 & 27,56 & 0,592 \\
\hline São João Batista & 86,5 & 67,4 & 30,39 & 0,592 \\
\hline $\begin{array}{l}\text { São Vicente } \\
\text { Ferrer }\end{array}$ & 81,4 & 66,4 & 35,16 & 0,571 \\
\hline Viana & 75,0 & 60,3 & 31,1 & 0,619 \\
\hline $\begin{array}{l}\text { Vitória do } \\
\text { Mearim }\end{array}$ & 69,5 & 50,9 & 40,6 & 0,615 \\
\hline
\end{tabular}

Fonte: Atlas do Desenvolvimento Humano, 2000/IBGE, 2002

Essa situação de precariedade tão acentuada precisa ser revertida, pois existe uma tendência de crescimento da população, como indicam os dados do IBGE (na Tabela 1), relativos à variação populacional nos últimos anos.

Para compreender os elementos contidos no quadro desse território da Baixada Maranhense, que retrata a pobreza e os índices do atraso ainda muito evidentes, é preciso destacar que existem elementos permanentes, de caráter estrutural, cuja origem é remota na história da colonização do país e existem elementos conjunturais que também se reproduzem, mantendo certo grau de continuidade, mas que podem em algum momento se modificar.

O que produz perplexidade ao viajante que percorre esse território é constatar o contraste entre a abundância de recursos naturais e a escassez que se reflete nas moradias precárias e nas condições de vida, de alimentação e de educação da população que habita a zona rural desses municípios. Poder-se-ia afirmar que boa parte dessa população parece estar vivendo na pré-história, mesmo quando a televisão está presente nas salas dos casebres como signo da "modernização" que alcançou até os locais mais distantes e isolados, na "periferia" das regiões longínquas do país.

Na realidade, a "modernização" ocorreu em muitas regiões, trazendo a tecnologia para aplicação no processo de produção agropecuária e também como política de financiamento da economia rural através de incentivos fiscais, mas, no Maranhão, pesquisas já publicadas apontam que essa política de modernização

(...) serviu de justificativa ideológica da ocupação, quase sempre fraudulenta (ASSELIN, 1986), de imensas glebas de terras do Estado do Maranhão pelo grande capital, durante o período autoritário, não passou de um mito. A 'modernização' local foi e continua muito pontual e desigual dentro da atividade. Tal fenômeno, no entanto, não é peculiar e essa etapa inicial perdura na década de noventa. Tampouco é específico do Maranhão, já que em áreas da Amazônia Legal processos semelhantes foram identificados com a expansão da pecuária. (VEIGA et alli, 2004; TOURRAND, 1997; BANCO MUNDIAL, 2003.)

\section{3- Estrutura fundiária e políticas de assentamento no território}

A emergência do capitalismo, no século XVII, colocou no centro do processo de Revista HISTEDBR On-line, Campinas, número especial, p. 5-27, out2011 - ISSN: 1676-2584 
dissolução das relações existentes nos feudos, a destruição das leis dos direitos comuns, cuja fonte de legitimação residia nos costumes que ganhavam força de lei. Para Carter, em Lex costumaria (1696), os pilares dos costumes são: a antiguidade, a constância, a certeza e a razão. Sir Edward Coke (1641), portanto antes de Carter, definia dois pilares dos costumes: o uso em comum e o tempo imemorial. (Thompson, 1998) ${ }^{3}$. Citando os referidos autores do século XVII, Thompson continua fazendo o esclarecimento sobre o que significa a lex loci ou seja a relevância do costume local.

(...) Quando um ato razoável, uma vez praticado, é considerado bom, benéfico ao povo e agradável à natureza e à índole das pessoas, elas o usam e praticam repetidas vezes, e assim, pela frequente iteração e multiplicação do ato, ele se torna costume; e se praticado sem interrupção desde tempos imemoriais, adquire força de lei. (Thompson, 1998, p. 86)

O resgate desses antecedentes históricos pode parecer supérfluo, entretanto, é importante que se compreenda de que modo foi construído historicamente o conceito de propriedade privada no campo. Segundo Thompson, " uma autoridade em direito rural sugere que os direitos comuns surgiram como direitos consuetudinários associados ao sistema de agricultura praticado nas comunidades primitivas das vilas" (1998, p.106). Adam Smith, ainda no século XVIII, já havia identificado como se mercadoriza a terra, passando-a a fazer render lucro para seus proprietários. Dizia Smith,

No momento em que toda a terra de um país se tornou propriedade privada, os donos das terras, como quaisquer outras pessoas, gostam de colher onde nunca semearam, exigindo uma renda, mesmo pelos produtos naturais da terra. A madeira da floresta, o capim do campo e todos os frutos da terra, os quais, quando a terra era comum a todos, custavam ao trabalhador apenas o trabalho de apanhá-los, a partir dessa nova situação têm o seu preço onerado por algo mais, inclusive para o trabalhador. Ele passa a ter que pagar pela permissão de apanhar esses bens, e deve dar ao proprietário da terra uma parte daquilo que o seu trabalho colhe ou produz. Essa porção, ou, o que é a mesma coisa, o preço dessa porção, constitui a renda da terra, constituindo, no caso da maior parte das mercadorias, um terceiro componente de preço. (SMITH, 1985, p. 79)

Essa realidade que é retratada por Thompson na Inglaterra, no século XVII e analisada por Smith, no século XVIII, não é diferente daquela que se constatou nas colônias em diversos continentes. No caso do Brasil, o sistema das capitanias hereditárias consagrou um modo "legal" de apropriação privada de terras comunais. Os primeiros habitantes das terras brasileiras eram os indígenas, entretanto aos olhos dos colonizadores, eles também poderiam ser incluídos como parte de suas posses, na medida em que fossem escravizados para realizarem os trabalhos necessários para o cultivo da terra e para a extração de recursos naturais.

No trabalho de Lacroix estão contidos preciosos registros do movimento que se deu na Baixada Maranhense, quando ocorreu a vinda dos franceses, em 1612, e depois com a definição do controle do Maranhão pelos portugueses, em que eram ressaltados os tesouros encontrados nessa região, inclusive o pau-brasil, cuja exportação para a Europa foi intensa. Segundo Lacroix, "o valor da Baixada Maranhense, como o de qualquer outra comunidade colonial, consistiu em ser, agora em meados do século XVIII, tanto exportadora de matéria-prima, quanto também consumidora dos produtos manufaturados ingleses." (1982, p. 24).

Os fatos históricos decorrentes da expansão do capitalismo concorrencial nas

Revista HISTEDBR On-line, Campinas, número especial, p. 5-27, out2011 - ISSN: 1676-2584 10 
colônias, enquanto se fortalecia o capitalismo industrial na Europa, explicitam a lógica que prevaleceu durante os períodos da história colonial e do império e, que ainda mostra seus vestígios na atualidade, em que o regime republicano no Brasil, em pleno século XXI, não alcançou a sua plenitude. Essas amarras do passado mostram a continuidade dos efeitos da lógica do capitalismo, que se expande sem limites e, ao mesmo tempo, estabelece o domínio dos mais fortes sobre os mais fracos, dos mais desenvolvidos sobre os menos desenvolvidos, dos mais ricos sobre os mais pobres, que continuarão sendo explorados e, portanto, empobrecidos, se não se libertarem da dependência estabelecida em relação aos grupos que detém o poder sobre a terra, o capital e o trabalho.

A descrição feita por Lacroix sobre a Baixada Maranhense nos séculos XVIII e XIX contém uma atualidade desconcertante como indício da reprodução do paradigma colonial ainda presente nessa região.

A economia da Baixada Maranhense, seguindo a vivida por todo o resto da América Portuguesa desde sua história colonial, e continuada por todo o período imperial, caracterizou-se pela cisão das atividades agrícolas. De um lado, a monocultura, grande lavoura com objetivo exportador, determinante de todo um contexto político-social. Do outro, a pequena lavoura, diversificada, determinada e condicionada aos interesses dos grandes latifundiários.

Tanto a agricultura de exportação quanto a de subsistência se caracterizaram por ínfimo nível tecnológico. Mesmo na fase de maior crescimento em que o Maranhão figurou como grande exportador, não foram usadas mais que as técnicas rudimentares conhecidas nos primórdios de sua colonização. Uma ou outra melhoria não significou um desenvolvimento agrícola qualitativo. (LACROIX, 1982, p.26)

Somente a partir dos anos 1980 do século XX, viu-se o ingresso de novas tecnologias na agricultura de exportação, mudando em certa medida a realidade do trabalho com a terra, mas no que diz respeito aos demais aspectos tem se mantido a continuidade do processo de expansão dos latifúndios e, mais recentemente, de uso intensivo de tecnologia para o plantio da soja e do arroz, produzindo, ao mesmo tempo a destruição de reservas florestais e a expulsão da população do campo, para a periferia dos municípios de pequeno e médio porte da região que não são capazes de absorver essa população flutuante, transformada em segmentos de trabalhadores avulsos, ambulantes, sem segurança, sem projeto de futuro.

Essas evidências recolocam a questão da terra como reserva de valor para o processo de acumulação do capital ${ }^{4}$. Assim foi na Inglaterra do século XVII, quando as terras, mediante a prática do cercamento foram definitivamente transformadas em bens privados, em mercadoria, destruindo os direitos comuns. Estamos distantes daquele período "inaugural" do capitalismo, mas essas práticas se reeditam no presente, embora sob novas formas, novos arranjos.

O Estado do Maranhão, com uma superfície de $329.555,8 \mathrm{~km}^{2}$, é a segunda unidade territorial do Nordeste em área. A densidade demográfica é de 14,96 hab/km, considerada muito baixa frente aos padrões nordestinos. Enquadrado na região nordeste, apresenta uma situação peculiar de localização transicional entre o Nordeste semiárido e a Amazônia úmida. Predomina em seu território a vegetação de floresta, gerando condições ambientais e socioeconômicas diferenciadas em relação aos demais estados do Nordeste.

Dados extraídos do Ramsar (Brasil, 1991. C:Idocsldiversosyicha_ramsar) permitem avaliar a riqueza desse território em termos de clima, regime de águas doces e salinizadas, recursos

Revista HISTEDBR On-line, Campinas, número especial, p. 5-27, out2011 - ISSN: 1676-2584 11 
hídricos, fauna, flora. A seguir estão apenas alguns dados que foram destacados pela sua importância para a caracterização do TR Campos e Lagos. Descrição resumida da área úmida extraída do Ramsar:

\begin{abstract}
"Terras baixas, planas, inundáveis, caracterizadas por campos, matas de galeria, manguezais e bacias lacustres. Solos argilosos pouco consolidados com grande capacidade de retenção de água, nos estuários, os manguezais ocorrem penetrando os igarapés, por entre os campos, até onde existe influência das marés. Na época das chuvas, entre dezembro e junho, os campos baixos ficam alagados restando "ilhas" de terra firme e uma área de campos em terreno um pouco elevado, o "teso".
\end{abstract}

O clima da região é úmido, com precipitação média anual da ordem de 1.700 a $2.100 \mathrm{~mm}$ e período seco muito curto, de um a três meses. O período chuvoso concentra-se nos meses de dezembro a julho. Face às características topográficas do Mearim as marés chegam a atingir até $170 \mathrm{Km}$ da foz, onde ocorre o fenômeno da pororoca (cuja velocidade de propagação no rio Mearim em média foi de $4,94 \mathrm{~m} / \mathrm{s}$ ou 9,59 nós, medida por Ferreira \& Kjerfve,(1990). A influência das marés associadas ao aumento do índice pluviométrico no interior do estado ocasiona as cheias nas planícies fluvio - marinhas. Em 1974 ocorreu uma cheia tão grande que atingiu em especial três cidades (Pedreiras, Ipixuna e Arari) prejudicando mais de 60.000 pessoas. Esse fenômeno das enchentes voltaram a atingir essas populações nos últimos anos.

Em sua grande maioria são lagos de várzea cuja área encontra-se sob domínio de depósitos fluviais, fluvio - lacustres e fluvio - marinhos. Os lagos recebem água quando os rios (Mearim, Pindaré, Grajaú e Turiaçu) sobem anualmente em virtude das cheias periódicas, a armazenam durante o período de inundação e a devolvem em parte para os rios quando seus níveis baixam. Face às oscilações anuais do nível das águas, fica difícil determinar o volume, a profundidade da área ocupada e a forma da bacia desses ecossistemas. O maior e mais importante lago é o Açu, onde há uma alta produtividade primária devido a grande biomassa algal, É um dos lagos mais piscosos da Baixada (incluindo camarão), tendo chegado a produzir na época do verão 15 toneladas de peixes por dia, segundo Lessa \& Cols, 1985.

A várzea maranhense pode ser considerada uma fonte de carbono importante. Sendo sua relevância para o equilíbrio ecológico da região muito grande; além da fertilidade de suas terras, os campos de várzea oferecem alimentação e locais de repouso e reprodução de numerosas aves aquáticas residentes ou migratórias. Considerando-se a região Nordeste, onde se insere o Estado do Maranhão, conforme divisão política do Brasil, como região biogeográfica é um ambiente único.

Os campos inundáveis da Baixada Maranhense diferenciam-se de outras áreas inundáveis sazonalmente na Amazônia ou perenemente como o pantanal devido à influência das marés e por consequência da intrusão salina, que conferem características peculiares a esta região do Brasil. A costa maranhense é a região que concentra grandes planícies fluviais e fluvio - marinhas, áreas planas e baixas, com altitudes predominantes entre 5 e 15 metros, recortadas por canais de circulação de águas salobras. Na sua maioria pode ser considerada ambiente quase natural ou relativamente antropizada devido a baixa densidade demográfica $26 \mathrm{hab} / \mathrm{Km} 2$. (Brasil, 1991. C:Idocsldiversoslficha_ramsar)

A distribuição populacional no estado do Maranhão indica que somente a partir de 1996, foi se alterando a relação entre a população rural e urbana, pois até 1991, $60 \%$ dos maranhenses encontravam-se na zona rural. Dados do IBGE de 2004 mostram que do total

Revista HISTEDBR On-line, Campinas, número especial, p. 5-27, out2011 - ISSN: 1676-2584 12 
de 6.036.607 habitantes, 4.111.010 $(68,10 \%)$ encontram-se na zona urbana, ficando $1.925 .597(31,90 \%)$ no campo. Destaca-se que no conjunto total de habitantes do estado, predomina o segmento feminino, com $3.071 .705(50,88)$. Os homens participam com $49,12 \%$, ou seja, totalizam 2.964 .902 habitantes.

De acordo com o Censo de 2010 os dados populacionais se alteram, mostrando que, mesmo constatando-se o crescimento da população urbana, também cresceu a população residente em áreas rurais, como se mostra a seguir. A população total do estado é de 6.574.789 pessoas. Na zona urbana estão 4.147.149 habitantes, enquanto residem na zona rural 2.427.640 pessoas. A população masculina é de 3.261.515 homens, sendo 1.995.845 habitantes da zona urbana, enquanto 1.265.670 habitam a zona rural. No caso das mulheres, a população total é de 3.313.274, estando 2.151.304 na zona urbana e 1.161.970 na área rural.

\section{1 - A ocupação do espaço em territórios da Amazônia Maranhense.}

Em 1956, no governo de Juscelino Kubitscheck foi criado o Grupo de Trabalho para o desenvolvimento do Nordeste (GTDN), coordenado por Celso Furtado, cujos resultados foram divulgados em 1959 no relatório Uma Política de Desenvolvimento Econômico para o Nordeste.

Entre outras recomendações estava a de que fosse planejada a ocupação do Maranhão como alternativa para reduzir as pressões das regiões nordestinas castigadas pela estiagem. A abertura da rodovia Belém - Brasília, no final da década de 50, foi o primeiro instrumento para que as migrações atingissem o Oeste do Maranhão e o sul do Pará. A partir de 1960, outros eixos rodoviários complementam o fluxo migratório de leste para oeste. A ocupação recomendada pelo GTDN provocou fluxos migratórios que avançaram rapidamente, causando transformações ambientais e quebrando as estruturas sociais e econômicas pré existentes. $\mathrm{O}$ avanço da atividade pastoril foi predominante, sendo acompanhada pela atividade madeireira que realizou a exploração das centenárias reservas florestais do Mearim, Pindaré, Tocantins e Gurupi.

O processo de ocupação inicia-se por posseiros, logo seguidos por grileiros que impõem um dos mais violentos processos de incorporação e desbravamento de áreas florestais. Grandes fazendas voltadas à exploração pecuária foram implantadas à custa de incentivos fiscais. Desta forma, instalaram-se na região latifúndios pertencentes a grandes empresas, grandes proprietários individuais e pequenos proprietários. A luta pela propriedade envolve os antigos ocupantes, incluindo fazendeiros tradicionais, posseiros e índios. Esta dinâmica de ocupação do território maranhense deu origem a muitos povoados, que na atualidade foram transformados em sedes municipais.

O resultado desse processo de ocupação pode ser constatado na BR-222, entre Açailândia e Santa Inês. A rodovia acompanha a margem direita do rio Pindaré, cortando a média bacia deste rio e a Ferrovia Carajás. O percurso é suficiente para evidenciar a fragilidade dos ambientes dessa área, tendo como consequência o assoreamento que vem atingindo as nascentes dos afluentes do rio Pindaré.

Devido à alta vulnerabilidade do ambiente, os cortes de estradas apresentam processos de erosão, com queda de material na pista de rolamento, etc. Santa Luzia, povoado criado em 1951 e transformado em município em 1959, é um exemplo desse processo de colonização. A ocupação da região só ganharia impulso na década de 70 com a expansão da fronteira agrícola para os vales do Pindaré, Buriticupu e Caru, inicialmente ocupados por lavradores oriundos de outras partes do Maranhão e dos estados vizinhos.

Nesse mesmo período a grilagem se instalaria na região, sendo famoso o grilo da

Revista HISTEDBR On-line, Campinas, número especial, p. 5-27, out2011 - ISSN: 1676-2584 13 
Fazenda Pindaré. A COMARCO, criada no início da década de 70 pelo governo estadual, recebeu terras alienadas do estado, objetivando a execução de projetos de colonização, ordenação das ocupações existentes e localização de médios e grandes projetos agropecuários. As ações discriminatórias promovidas pelo governo para legalizar as grandes glebas foram utilizadas como um meio de exclusão dos posseiros que por não terem acesso aos jornais e aos editais, só tomavam conhecimento quando um juiz promovia seu despejo. Da área de 200.000 hectares reservada pela COMARCO para assentamento de pequenos agricultores, menos de 80.000 foram entregues, sendo o resto ocupado por grandes empresas ou grileiros.

A área destinada à colonização situava-se em meio das áreas de grandes empresas, porém em áreas secas, normalmente localizadas nas partes mais elevadas. Buriticupu é o exemplo típico dessa situação, onde muitas famílias tiveram que abandonar seus lotes. Transformado em município, o antigo povoado era um aglomerado de casas de madeira, distribuídas sem nenhuma organização urbanística, com as ruas empoeiradas que se transformavam em lamaçais na época da chuva. O estado de pobreza da população era facilmente percebido, provocando uma acentuada desestruturação social que atingiu principalmente os jovens. Constituiu-se numa região com elevada tensão social, tendo inclusive ocorrido diversas mortes em conflito de terra no ano de 1996.

O projeto Colone foi outro exemplo do abandono da reforma agrária na região. Concebido para ser um dos maiores projetos de assentamento do mundo, utilizando inclusive tecnologia israelense, o projeto ocupou mais de 1.000 .000 de hectares, com 15.000 famílias assistidas, tendo sido titulados mais de 2.000 lotes, restando outro tanto em processo de titulação. Decorrente de um convênio com o Banco Mundial, o projeto foi quase completamente desmantelado na administração Collor, existindo atualmente até plantações de maconha no mesmo. (IBGE, 1997).

Os projetos agropecuários dos anos 1970, de exploração mineral dos 1980 e de expansão da fronteira da agricultura extensiva nos 1990 e 2000, continuaram provocando grandes impactos: a violência no campo, o deslocamento de numerosos segmentos da população do campo para as cidades, agravando-se os problemas de falta de infraestrutura, saneamento, habitação, emprego e a concentração fundiária, que o coloca como um dos estados da federação em que esse índice é muito elevado.

Outro indicador que chama atenção é ter sido constatado na PNAD de 2006 (IBGE) que $75,4 \%$ dos trabalhadores no meio rural são autônomos, ou seja, trabalham por conta própria e também se constata elevado percentual de empregados não remunerados. (SILVA, 2008, p.24). Dados da Comissão Pastoral da Terra indicam a gravidade do quadro de conflitos que ainda nos anos 1990, decorreram da luta pelo direito à terra, que continuou sendo usurpado, principalmente, pela invasão das empresas em áreas supostamente devolutas.

Quadro 1 - Conflito de terras no Maranhão (1997-1998)

\begin{tabular}{|l|l|l|l|}
\hline CONFLITO & MUNICÍPIO & ÁREA (ha) & ENVOLVIDOS \\
\hline $\begin{array}{l}\text { Santa Filomena/Ypioca/Pecem } \\
\text { Agroindustrial }\end{array}$ & Santa Rita & 100 \\
\hline Fazenda Alvorada & Amarante do Maranhão & 30.000 & 206 \\
\hline Cachuca/Caxuxa/Jacu/São Pedro & Santa Luzia & 500 & 12 \\
\hline Lagoa Santo Agostinho & Magalhães de Almeida & & \\
\hline Povoado Cipó & Coelho Neto & 900 & 50 \\
\hline Gleba Santa Rosa & Araioses & \multicolumn{2}{|l|}{} \\
\hline Povoado Santa Rita & Lago do Junco & 17 \\
\hline
\end{tabular}

Revista HISTEDBR On-line, Campinas, número especial, p. 5-27, out2011 - ISSN: 1676-2584 14 


\begin{tabular}{|l|l|l|l|}
\hline $\begin{array}{l}\text { Faz.Pingo de } \\
\text { Ouro/Cavalcanti/Naja/Pindaré }\end{array}$ & João Lisboa & 50 \\
\hline Povoado Engenho D'água & Caxias & 15.000 & 900 \\
\hline Povoado Colier & São Luís & & 18 \\
\hline Correguinho/Corguinho & Açailândia & & 45 \\
\hline Criação de Búfalos & Cajari & 7 & 7 \\
\hline $\begin{array}{l}\text { Fazenda Lote 7/ Lote Seco/André } \\
\text { Yane }\end{array}$ & Imperatriz & 2.814 & 100 \\
\hline Fazenda União & Imperatriz & 5.000 & 350 \\
\hline Povoado Livramento & Codó & & 1 \\
\hline Panaca/Panamerim & Pirapemas & 2.500 & 30 \\
\hline Flor do Vale & Imperatriz & \multicolumn{2}{|l|}{} \\
\hline
\end{tabular}

Fonte: CPT - Comissão Pastoral da Terra In: ZYLBERSZTAJN, Decio et al. Reorganização do agronegócio do babaçu no Estado do Maranhão. São Paulo, Fundação Instituto de Administração/ Faculdade de Economia, Administração e Contabilidade da USP, 2000.

A Baixada Maranhense tem problemas fundiários similares às outras regiões do estado. As soluções que estão sendo criadas para esses problemas se concretizam de forma muito lenta. Recentemente, (março 2010), foi divulgada nova iniciativa dos Governos Federal e Estadual no sentido de agilizar alguns processos de regularização fundiária através do Programa Terra Legal. Informações oficiais indicam que em áreas urbanas de 16 municípios serão realizadas ações de regularização. Entre os municípios selecionados está o de Vitória do Mearim (Jowberth Frank Alves - coordenador do Programa no Maranhão).

Dos 217 municípios que compõem o estado, 180 estão localizados na Amazônia Legal, sendo que desses, 28 possuem Glebas Públicas Federais, com uma estimativa de 6.755 imóveis rurais a serem regularizados pelo Terra Legal. Ainda que tenha sido promovido esse "avanço", a questão da terra no Maranhão e na região da Baixada Maranhense tende a produzir novos efeitos diante da expansão da fronteira agrícola que continua a se deslocar do sul do Maranhão, onde se instalou definitivamente a monocultura da soja, para o oeste do estado, fazendo um roteiro de transformação da realidade agrária e agropecuária sem precedentes, pelo ritmo em que se realizam as etapas de implantação dos projetos e pelo efeito devastador que atinge a natureza e os seres humanos que habitam essas regiões.

Na Baixada Maranhense, no levantamento recente do cadastro do INCRA, mais particularmente no território Campos e Lagos, obteve-se o registro de apenas um assentamento, e ainda assim ele foi cancelado, no município de Viana. É claro que essa constatação poderia permitir trabalhar com a hipótese de que as terras estão regularizadas e não existe o problema da propriedade do solo, para os agricultores desse território. Entretanto, os resultados de pesquisa de campo realizada pelo Instituto Formação revelam que ainda existe um grande número de agricultores trabalhando em terras arrendadas e em áreas em parceria. No quadro abaixo constam dados dos vários municípios do território confirmando essa afirmação.

Do total de 2069 entrevistados nos municípios do TR Campos e Lagos, constatouse que $57 \%$ ocupam área própria, nas áreas em parceria estão $13 \%$ dos agricultores, enquanto $17 \%$ encontram-se em área arrendada, sendo que, em área de condomínio há 4\% de ocupação. Em outras fontes secundárias sobre a situação dos assentamentos no Maranhão, encontrou-se a seguinte afirmação: “(...) A Baixada Maranhense é outra microrregião que desponta no quantitativo de assentamentos nos últimos dez anos, período em que foram criados $84,6 \%$ dos projetos existentes no presente momento, sendo que 58,4\% destes surgiram nos últimos seis anos.” (SILVA, 2008, p.231). 
O referido autor, em tabela elaborada a partir de dados do INCRA, (SILVA, 2008, p.230) indica os seguintes números da Baixada Maranhense:

\begin{tabular}{|l|l|ll|r|r|r|}
\hline Microrregião & \multicolumn{1}{|l|}{$\begin{array}{l}\text { Pa } \\
\text { Famílias }\end{array}$} & \multicolumn{5}{|c|}{ Área (Ha) } \\
\hline Baixada & Total & Total & Lote Médio & Total & PA Médio \\
\cline { 2 - 8 } Maranhense & 93 & & 8.988 & 20,26 & 182.110 & $1.958,17$ \\
\hline
\end{tabular}

Feito um balanço da concentração de assentamentos por microrregião, SILVA (2008, p.233) analisa que a microrregião do Pindaré é a que concentra o maior número de assentamentos, o que equivale a uma área igual ou superior a 10 mil hectares no estado do Maranhão. Agrupando-se Pindaré, Gurupi, Alto Mearim e Grajaú, e ainda os Lençóis Maranhenses, tem-se $77 \%$ dos projetos identificados nessas microrregiões, abrangendo $75 \%$ da área destinada aos assentados e com o envolvimento de $40 \%$ das famílias.

De acordo com o INCRA, a área total ocupada pelos assentamentos corresponde a 4,1 milhões de hectares, o que seria suficiente para receber 120,4 mil famílias. Entretanto, até o ano de 2006, tinham sido assentadas 94,3 mil famílias, o que significa a existência de vagas para 26,1 mil famílias. (SILVA, 2008,p.235). Ainda é necessário destacar, segundo avaliação do INCRA, que $65 \%$ dos 826 assentamentos encontram-se na fase de estruturação, o que causa certa perplexidade, considerando-se que 16,6\% foram criados há mais de 10 anos. Somente 4\% são considerados consolidados e entre estes o mais antigo tem 35 anos e o mais recente tem 7 anos.

Há também uma diluição dessas áreas pelos municípios que compõem cada microrregião, que talvez dificulte ainda mais o processo de consolidação, considerando-se que os demais fatores que precisam ser agregados ao acesso a terra, definem em grande medida a permanência ou não das famílias nas áreas de assentamento.

Dados fornecidos pelo INCRA, utilizados por SILVA (2008, p. 304), mostram que no caso da Baixada Maranhense a distribuição das famílias por área, em cada município da microrregião permite uma visão quantitativa acerca da totalidade dos assentamentos, entretanto sabe-se que uma visão qualitativa é indispensável para que se possa avaliar os resultados da política de assentamento, mediante o processo de regularização fundiária.

Chama atenção o fato dos lotes desses assentamentos serem extremamente reduzidos em sua maioria, decorrente da insuficiente área destinada a assentamentos em determinados municípios, como é o caso de São Bento e São Vicente Ferrer, com lotes de no máximo 3,0 hectares, o que viabilizaria apenas poucas atividades produtivas e certamente levaria este assentado a ter que optar por uma especialização, algo não desejável para a situação de um agricultor familiar. Dados mais recentes, do ano de 2010, mostram como segue se realizando de forma muito lenta a questão da regularização fundiária em municípios do TR Campos e Lagos, até porque não existe nenhum título expedido para áreas desse território, conforme dados do Instituto Nacional de Colonização e Reforma Agrária - INCRA, Sistema de Informações de Projetos de Reforma Agrária (SIPRA),Relatório Acordão TCU - 11/02/2010.

Também existe uma grande lacuna no que diz respeito aos estudos verticalizados que abrangem as dimensões qualitativas e quantitativas, em relação ao processo de implantação e consolidação dos assentamentos. Somente em nível de avaliação mais geral foi realizada uma pesquisa que trata da qualidade dos assentamentos no Brasil. Spavorek (2003) verificou que o fato de se atribuir como mecanismo mais importante do processo de reorganização fundiária o acesso à terra, não significa que outros fatores não possam ter grande impacto sobre a qualidade desse processo. Entre outros foram destacados os 
seguintes: a) acesso ao atendimento de saúde em caso de emergências; b) acesso à água de boa qualidade; c) acesso ao ensino médio; d) tratamento de esgoto doméstico.

Constatando-se na maioria dos assentamentos a pouca disponibilidade desses fatores, fica evidente a ineficácia das políticas e ações que não estão concebidas e executadas de modo integrado e intersetorial. Ou seja, garantir apenas o acesso à terra, não quer dizer garantir condições de vida e de trabalho para os trabalhadores e trabalhadoras, em regiões muito isoladas e, muitas vezes, inóspitas.

Nessa pesquisa realizada no TR Campos e Lagos a indisponibilidade da água foi destacada pelos entrevistados como uma das grandes dificuldades a se enfrentar no campo. Quando indagados sobre as formas que utilizam para enfrentarem esse problema da água, $883(17 \%)$ afirmaram que utilizam poço cacimbão, $266(5 \%)$ usam poço artesiano, 235 $(5 \%)$ tem acesso a açude.

Nem de longe, pode-se conceber que essas alternativas contemplem a dimensão da quantidade e da qualidade da água necessárias para o abastecimento dessa população, portanto, medidas urgentes e impactantes devem ser adotadas e implementadas pelas três esferas do poder executivo no país.

\section{2- A luta e a conquista de terras quilombolas}

$\mathrm{O}$ quadro de regularização das terras quilombolas, de algum modo, expressa os avanços e recuos das políticas governamentais nesse setor. O reconhecimento tardio da posse de áreas cujos verdadeiros proprietários foram desapropriados por outros "donos das terras no Maranhão", coloca nas mãos dos herdeiros de gerações ancestrais a possibilidade de cultivarem essas áreas para garantirem a sua sobrevivência. Porém, esses segmentos necessitam de muito mais apoio e financiamento para poderem alcançar sua autonomia através do trabalho, produção e renda. Um quadro geral da situação de regularização de terras quilombolas indica o quantitativo de famílias contempladas por estado. No Maranhão, 1.548 famílias foram beneficiadas, sendo que no TR Campos e Lagos foram apenas 44 famílias no município de Pedro do Rosário.

Segundo o Centro de Cultura Negra do Maranhão, existem 527 comunidades quilombolas no Estado do Maranhão, distribuídas em 134 municípios. Elas concentram-se principalmente nas regiões da Baixada Ocidental, da Baixada Oriental, do Munim, de Itapecuru, do Mearim, de Gurupi e do Baixo Parnaíba. O Estado do Maranhão é um dos cinco no Brasil cuja constituição reconhece às comunidades quilombolas o direito à propriedade da terra. Essa garantia é fruto da luta do movimento negro, que conseguiu a inclusão do artigo 229 na Constituição Estadual do Maranhão, promulgada em 1989. Até outubro de 2007, 20 comunidades quilombolas maranhenses haviam conquistado o título de propriedade de suas terras. Os títulos foram outorgados pelo governo do estado por meio do Instituto de Terras do Maranhão (Iterma).

A comunidade Frechal teve suas terras transformadas em reserva extrativista por meio do Decreto Federal $\mathrm{N}^{\circ}$ 536/1992. Essa área não consta na tabela de terras tituladas porque a mesma não é de propriedade dos quilombolas. A reserva extrativista é uma categoria de unidade de conservação. É de domínio público com uso concedido às populações extrativistas tradicionais. Além dessa reserva, foram criadas mais três.. Entretanto, somente foi efetivada a reserva do Quilombo do Frechal (ALMEIDA, 2001, p.61).

O Maranhão é o segundo estado brasileiro com maior número de terras de quilombolas tituladas, atrás apenas do Pará. Essas e outras conquistas são fruto da árdua 
luta dos quilombolas maranhenses articulados na Associação das Comunidades Negras Rurais Quilombolas do Maranhão (ACONERUQ). Nessa trajetória de luta os quilombolas contam com o apoio do Centro de Cultura Negra do Maranhão, a Sociedade Maranhense de Direitos Humanos e o Ministério Público Federal.

A ação pioneira dessas duas organizações teve início com o Projeto Vida de Negro (PVN) na década de 1980. O projeto teve como objetivo identificar e produzir estudos sobre as comunidades quilombolas maranhenses para subsidiar a luta pela regularização de seus territórios. Até julho de 2007, o PVN havia mapeado 527 comunidades e assessorado na produção de 33 processos de titulação de terras junto ao INCRA e ao ITERMA.

Entretanto, sabe-se que no município de Alcântara, localizado a 22 quilômetros de São Luís, numa área de 114 mil hectares, com uma população de 22 mil habitantes, há quase trinta anos está dada a situação de conflito que foi provocada pela instalação do Centro de Lançamento de Alcântara que abriga uma Base Espacial, ocupando 62.000 hectares que corresponde a metade da área municipal. Por meio de Decretos da Presidência da República de 1980 e 1991, foi determinada a desapropriação dessa área, em que habitavam comunidade remanescentes de quilombolas.

Em Laudo Antropológico publicado por Almeida (2006), por determinação do Ministério Público Federal em 2002, ficaram explicitados os impactos desse processo de deslocamento de 32 comunidades quilombolas transferidas para sete agrovilas. Estas e as demais comunidades do município, apesar de todas as iniciativas empreendidas pelas organizações locais como o MABE - Movimento dos Atingidos pela Base Espacial de Alcântara, não conseguiram alcançar seu objetivo maior, qual seja obter a regularização fundiária de suas terras. Essa desapropriação das comunidades do seu território étnico tem sido tema de debates, de pesquisa, de denúncias feitas nas Nações Unidas, que ainda não produziram o efeito da titulação.

As mulheres e os homens quilombolas no Maranhão foram pioneiros na luta pela garantia dos seus direitos. Como avalia Ivo Fonseca, liderança quilombola que atualmente ocupa o cargo de Gestor de Políticas para Comunidades Tradicionais da Secretaria Extraordinária de Igualdade Racial do Maranhão, a principal vitória do movimento quilombola maranhense é o seu fortalecimento.

No ano de 1997, os quilombolas do Maranhão fundaram a Associação das Comunidades Negras Rurais Quilombolas do Maranhão, conhecida como ACONERUQ, com o objetivo geral de servir como fórum de representação dos quilombolas do estado. Em setembro de 2007, 423 comunidades maranhenses estavam vinculadas à instituição. Seus objetivos específicos: fortalecer a organização do movimento quilombola e, ainda, lutar em conjunto com as comunidades pela regularização de suas terras. Para isso, a associação incentiva a participação política dos quilombolas, organizando cursos de capacitação e criando oportunidades de troca de experiências sobre os problemas enfrentados pelas comunidades.

Entre as conquistas da ACONERUQ estão a criação da Reserva Extrativista de Frechal e a titulação de 20 territórios quilombolas até setembro de 2007. A ACONERUQ teve participação ativa também na fundação da Coordenação Nacional de Articulação das Comunidades Negras Rurais Quilombolas (CONAQ) que articula comunidades quilombolas de diversos estados. Os quilombolas batalham ainda para assegurar direitos básicos, como o acesso à saúde, à educação formal, à capacitação profissional, à melhoria das condições de trabalho e de geração de renda. 


\section{3- As quebradeiras de coco - extrativistas em processos de produção e organização}

Em maio de 1992 foram criadas por decreto federal quatro reservas extrativistas na região Tocantina, sendo três delas no Maranhão e uma em Tocantins. Juntas somam 36.322 hectares e possuem uma população estimada em 3.350 pessoas. (Queiroz, 1999)

O processo de cercamento de terras, ou seja, de privatização de terras inclusive da União e do Estado pelos latifundiários resultou na expulsão dos trabalhadores das áreas em que plantavam suas roças, fazendo cultivos que garantiam a sua sobrevivência, como a mandioca, o milho, o feijão. Essas áreas foram sendo transformadas em pastagens e as famílias dos trabalhadores do campo foram sendo obrigadas a dedicarem-se à prática do extrativismo, como única forma de garantir a sua sobrevivência.

Entretanto, o acesso aos babaçuais também gerou a reação dos latifundiários para impedir que os homens e mulheres tirassem dali seu sustento. Foi o enfrentamento desses poderosos donos de terras em várias regiões do Maranhão, que permitiu a conquista da terra e a consagração de sua prática de trabalho, através da definição legal do acesso ao babaçu livre ( Lei do Babaçu Livre - anos 1990).

As mulheres quebradeiras de coco do Maranhão foram pioneiras no processo de organização, desde os anos 70, a partir das Comunidades Eclesiais de Base. Foram fundadas várias entidades, destacando-se a Associação de Mulheres Trabalhadoras Rurais - AMTR, a Associação em Áreas de Assentamento do Maranhão - ASSEMA, Movimento Interestadual de Quebradeiras de Coco (MIQCB). Está estruturado em seis regionais: Pará, Piauí, Tocantins, Imperatriz, Baixada, Mearim. São promovidos Encontros Interestaduais a cada três anos, reunindo 240 quebradeiras que discutem e aprovam o Plano de Ações Interestaduais do MIQCB. Centenas de mulheres organizadas em grupos, cooperativas e associações produzem artesanato, sabonetes, sabão, massa de babaçu, azeite, carvão vegetal, óleo e resíduo para a ração animal.

Segundo Mesquita (2008, p. 58), é inusitado o fato de serem as quebradeiras de coco, vítimas de um processo de produção e reprodução das desigualdades no Maranhão, aquelas que mais se empenham em lutar pela preservação do meio ambiente, do desenvolvimento sustentável, ocupando um espaço da sociedade civil, em que assumem a sua condição de sujeitos coletivos, com compromisso de lutar contra a injustiça e a favor da melhoria das condições de vida dos mais empobrecidos, pelo modo como se desenvolveu e se desenvolve o capitalismo no Brasil e no Maranhão.

Nesse sentido, a estratégia passa pela cobrança de posição, mobilização e organização de encontros, oficinas, audiências públicas e debates, com diferentes segmentos da sociedade, envolvendo governos e instituições públicas e privadas. Além de se qualificarem, as mulheres agroextrativistas se fortalecem, institucionalmente, com apoio de ONGS (nacionais e internacionais) e até de governos estrangeiros, via cooperação internacional, a exemplo da Grã-Bretanha (Departamento Internacional de Fundos para o Desenvolvimento - DFID e da União Européia. ( MESQUITA, 2008, p. 58) 
Em relação à realidade do TR Campos e Lagos, a superação da pobreza somente ocorrerá mediante investimentos simultâneos em políticas de educação, saúde, agricultura. Abaixo seguem dados de demandas específicas da população do campo no TR Campos e Lagos ao Ministério de Desenvolvimento Agrário.

Quadro 2 - Segmentos do TR Campos e Lagos

\begin{tabular}{|l|r|l|r|r|r|}
\hline \multicolumn{7}{|c|}{ Território 141 - Campos e Lagos - MA } \\
\hline Município & $\begin{array}{l}\text { Agricultores } \\
\text { Familiares (1) }\end{array}$ & $\begin{array}{l}\text { Famílias } \\
\text { Assentadas } \\
(\mathbf{2})\end{array}$ & \multicolumn{1}{l|}{ Pescadores } & $\begin{array}{l}\text { Terras } \\
\text { Indígenas }\end{array}$ & Quilombolas \\
\hline Arari & 1.415 & 503 & 2.257 & 0 & 0 \\
\hline Cajari & 1.993 & 167 & 1.060 & 0 & 3 \\
\hline Matinha & 1.903 & 182 & 1.183 & 0 & 0 \\
\hline Olinda Nova do Maranhão & 2.507 & 148 & 105 & 0 & 0 \\
\hline Palmeirândia & 1.897 & 751 & 325 & 0 & 0 \\
\hline Pedro do Rosário & 1.100 & 1.116 & 95 & 0 & 0 \\
\hline Penalva & 2.676 & 389 & 527 & 0 & 1 \\
\hline São Bento & 2.056 & 28 & 626 & 0 & 0 \\
\hline São João Batista & 2.117 & 0 & 493 & 0 & 0 \\
\hline São Vicente Ferrer & 2.152 & 38 & 0 & 0 & 0 \\
\hline Viana & 3.084 & 638 & 877 & 0 & 0 \\
\hline Vitória do Mearim & 1.091 & 2.094 & 1.461 & 0 & $\mathbf{4}$ \\
\hline Total Território & $\mathbf{2 3 . 9 9 1}$ & & $\mathbf{9 . 0 0 9}$ & $\mathbf{0}$ & 0 \\
\hline
\end{tabular}

É esse conjunto de trabalhadores e trabalhadoras que assegura uma pequena produção nesse território, considerada insuficiente para a demanda da população e para a sua própria subsistência com dignidade. É importante não se perder de vista que na região convivem tanto as motivações históricas de desigualdades que marcaram o processo de ocupação do território nordestino, desde o período colonial, como a economia escravista e as grandes propriedades pastoris do sertão, quanto às regiões de cerrado do oeste baiano, nas quais a expansão da soja, inserida em um pacote tecnológico e o elevado grau de articulação com o comércio mundial de commodities agrícolas impõem uma escala de grande produção como pressuposto para inserção no mercado (IBGE, Censo Agropecuário, 1985/2006, p. 109).

Esse conjunto de dados obtidos, a partir do Censo Agropecuário de 2006, possibilita uma análise comparada entre as regiões e entre os usos da terra, deixando ver claramente que a economia rural está principalmente ancorada em estabelecimentos de menos de 10 ha (47,0\%), ocupando menos de 2,7\% do território, enquanto os estabelecimentos de mais de 1000 ha $(43,0 \%)$ totalizam $0,91 \%$ dos estabelecimentos.

Foram identificados 4.367.902 estabelecimentos de agricultores familiares, o que representa $84,4 \%$ dos estabelecimentos brasileiros. Este contingente de agricultores familiares ocupava uma área de 80,25 milhões de hectares, ou seja, 24,3\% da área ocupada pelos estabelecimentos agropecuários brasileiros. Estes resultados mostram uma estrutura 
agrária concentrada no país: os estabelecimentos não familiares, apesar de representarem $15,6 \%$ do total dos estabelecimentos, ocupavam $75,7 \%$ da área ocupada. A área média dos estabelecimentos familiares era de 18,37 ha, e a dos não familiares, de 309,18 ha.

Ainda que exista essa constatação de aumento da participação da agricultura familiar no total de estabelecimentos do país, esse quadro mostra que está longe de se poder considerar adequada a condição de trabalho oferecida aos segmentos dos trabalhadores e trabalhadoras, pois amplia-se a contradição entre a atividade agropecuária das grandes empresas e a produção no nível da agricultura familiar, principalmente pelo fato de se ampliar a área destinada às pastagens, em função da ampliação da atividade pecuária.

No Maranhão, segundo dados do Censo Agropecuário (2006), existe um significativo avanço na direção à especialização, domínio e predomínio de pastagens na pré- Amazônia Maranhense e em amplas áreas do Estado nas quais a pecuária pode apresentar alto rendimento econômico, aliado à promoção da imagem e o estilo de vida rural moderno; a lavoura e o extrativismo, perde espaço como remanescente da produção do pequeno produtor descapitalizado.

\section{4- Perspectivas da educação para o futuro dos trabalhadores e trabalhadoras em territórios rurais}

O cenário de precariedade da educação ofertada no TR Campos e Lagos afeta o desenvolvimento das pessoas e das cidades que o compõem. O elevado índice de analfabetismo também é um dos fatores que agudizam o baixo nível de desenvolvimento desse território. Além da alfabetização, escolarização e qualificação profissional permitirem a elevação da escolaridade do jovem e do adulto, também permitem o acesso ao mundo do conhecimento escolar e profissional, sem o que o desenvolvimento humano fica restrito e limita a própria condição de existência.

$\mathrm{Na}$ atualidade, os debates sobre o conceito de alfabetização ou das formas e modalidades de qualificação profissional ampliam esse conceito, abrangendo conteúdos relativos ao uso da informática e dos recursos da internet. As novas tecnologias concentram as informações do que acontece no nível global, garantindo sua divulgação em grande velocidade, em intervalos de tempo cada vez mais reduzidos. Esse quadro indica a necessidade premente de inclusão digital de toda a população, seja urbana ou rural, para que possam ser garantidos processos de formação continuada.

Quando se pensa a "adequação do ensino" a essas modificações que se produzem no mundo do trabalho e impõem exigências do modelo da sociedade vigente, articulado em nível mundial, é fundamental elaborar políticas voltadas para a viabilização de novas diretrizes de educação que alcancem todos os segmentos definidos a partir de gênero, etnia e geração, como critérios que levem em conta esse processo mais amplo, ultrapassando os limites que são impostos pelo próprio processo de desenvolvimento do capitalismo.

No Brasil, por exemplo, ao longo da sua história de educação profissional foram as regras e os interesses do capitalismo que referenciaram essa política educacional. $\mathrm{O}$ foco não era o jovem e o adulto, mas as necessidades do mercado, portanto, onde estavam as indústrias havia preparação para o trabalho, regra geral, a partir das demandas do mercado e não de definições do Ministério da Educação.

No caso da agricultura familiar, o trabalhador necessita de assistência externa,

Revista HISTEDBR On-line, Campinas, número especial, p. 5-27, out2011 - ISSN: 1676-2584 21 
entretanto os técnicos e profissionais formados nos cursos relacionados à área de agropecuária produzem conhecimento e tecnologia que estão, prioritariamente, relacionados ao fortalecimento do agronegócio. Os poucos investimentos em assistência técnica (ATER) não alcançam o trabalhador na ponta. Além disso, a desvalorização da produção da agricultura familiar produz como efeito simbólico e ideológico a resistência dos jovens em relação ao trabalho no campo, como se essa prática fosse considerada inferior e, portanto, uma "punição".

As comparações entre a produção de toneladas de grãos pelo agronegócio e a produção restrita dos assentados da reforma agrária, comumente, aponta os últimos como improdutivos. Entretanto, a monocultura da soja, por exemplo, expressa um conceito de produtividade que interessa somente ao grande capital, pois sua finalidade está ligada ao setor de exportação de grãos para alimentar animais, gado (bovino, suíno, ovino) e aves em geral. Por outro lado, a dieta alimentar diária dos brasileiros depende, em grande medida, da agricultura familiar, que é praticamente desconhecida para a maior parte da população, em todas as regiões.

A oferta insuficiente de educação básica e de educação profissional no campo tem contribuído, fortemente, para a expulsão de muitos jovens e adultos para os centros urbanos, em direção a muitos outros estados, na condição de trabalhadores levados a realizar formas de trabalho análogas à escravidão, como passou a ser definido, nos primeiros anos do século XXI.

Frigotto critica a separação trabalho intelectual/trabalho manual, afirmando:

$\mathrm{Na}$ perspectiva das classes dominantes, historicamente, a educação dos diferentes grupos sociais deve dar-se a fim de habilitá-los técnica, social e ideologicamente para o trabalho. Trata-se de subordinar a função social da educação de forma controlada para responder às demandas do capital. (FRIGOTTO, 1996:26)

Existem possibilidades de desenvolvimento e elevação da qualidade de vida dos trabalhadores do campo, no âmbito material e simbólico, mediante acesso diferenciado a outros universos de conhecimento e de cultura que precisam ser garantidos, mediante a realização de políticas públicas mais consistentes e voltados para os segmentos que historicamente tem sido excluídos do acesso à ciência, à literatura e à pedagogia. Sem esses instrumentos a população que habita áreas rurais tem sido submetida ao controle das elites, que se realiza das mais diferentes formas.

Essa realidade, contudo, não impediu que grupos de pessoas, em diferentes partes do país, articuladas ou não, continuassem a lutar por transformações no campo econômico, político e social, como continuassem também a contribuir para avanços no campo educacional, especificamente na educação de jovens e adultos via os processos de alfabetização e de qualificação profissional.

É possível constatar que não é apenas a questão da erradicação do analfabetismo, via universalização de ensino e oferta de modalidades educativas para jovens e adultos não-escolarizados, que deve ser motivo de preocupação do poder público e da sociedade civil organizada. Deve-se priorizar também a discussão sobre um processo educativo que garanta a qualidade de ensino e de aprendizagem de forma contextualizada e ampliada. Especificamente no TR Campos e Lagos um movimento iniciado em 2003, somado às políticas do governo federal e dos governos dos municípios têm possibilitado alguns pequenos, mas significativos acessos e avanços no campo da formação e qualificação de 
jovens e adultos.

Isso tem ocorrido a partir da construção de uma ampla rede de aliados, que envolveu juventude, organizações da sociedade civil e governos municipais, como atores de um processo permanente de formação e de criação de alternativas voltadas para o desenvolvimento sustentável das cidades e melhoria da educação ofertada nos municípios dessa região, acreditando que o processo educacional seria uma das possibilidades de transformação da escassez ali existente em abundância, a partir da transformação das potencialidades naturais e humanas em meios de vida sustentáveis. Toda essa história conhecida como CIP Jovem Cidadão está sendo pesquisada e registrada.

\section{5- Conclusão}

A imersão que se tem feito no TR Campos e Lagos, desde 2003, permite-nos afirmar que a sua riqueza reside na biodiversidade que abriga e na potencialidade de seus habitantes: jovens, trabalhadores e trabalhadoras nas cidades, sede dos municípios, e no campo, nos povoados que configuram esse território.

A pesquisa realizada pelo Instituto Formação, através de entrevista com 2069 trabalhadores e trabalhadoras, representa uma amostra que expressa elevada representatividade do que pode se considerar como situações que são generalizadas, na maioria dos territórios rurais, pois as atividades produtivas retratadas e as condições de vida e de trabalho dos trabalhadores e trabalhadoras se reproduzem em quase todas as regiões do Estado do Maranhão.

Afinal, as questões estruturantes como a distribuição e uso da terra, o acesso ao crédito, a demanda por assistência técnica, a qualificação profissional voltada para o desenvolvimento local, a garantia de acesso aos serviços de qualidade na área da educação, saúde e infraestrutura, são as mesmas que ocorrem nos demais territórios, variando apenas em graus, para mais ou para menos, no que diz respeito à materialização de políticas públicas, em benefício da população.

Essa população de trabalhadores e trabalhadoras compreende o conjunto de agricultores familiares, quilombolas, quebradeiras de coco, pescadores, extrativistas, meliponicultores, que compõem o mosaico do território humano e físico dos campos e lagos, contendo um elemento que aproxima todos os segmentos, embora cada um deles tenha identidade própria e histórias de luta e de conquistas diferenciados, em termos espaciais e temporais.

A terra é a variável constante que tanto acolhe como expulsa os trabalhadores, tornando-os reféns dos processos medievais de cercamento que se reproduzem, sob novas modalidades de apropriação dos territórios pelos setores do agronegócio, transformando-os em novas gerações de trabalhadores sem terra, sem teto e, portanto, integrantes dos contingentes que vendem a sua força de trabalho para a exploração análoga a que se praticou com os escravos, quando não são exterminados, como ocorreu em vários estados brasileiros, incluindo o Maranhão, em que a luta pela terra transformou-se numa guerra entre desiguais.

Saramago relembra essa situação do Brasil, em artigo publicado no site do MST, quando resgata dados de dois episódios de demonstração da força e violência dos latifundiários. "Os 19 mortos de Eldorado dos Carajás e os 10 de Corumbiara foram apenas a última gota de sangue do longo calvário que tem sido a perseguição sofrida pelos trabalhadores e trabalhadoras, uma perseguição contínua, sistemática, desapiedada, que, só entre 1964 e 1995, causou 1635 vítimas mortais, cobrindo de luto a miséria dos camponeses de todos os estados do Brasil. com mais evidência para Bahia, Maranhão, 
Mato Grosso, Pará e Pernambuco, que contam, só eles, mais de mil assassinados”.

Situações semelhantes a essas ocorreram também no Maranhão, principalmente, nos anos 70, quando a política governamental "propiciou a titulação e a demarcação irregular de grandes extensões de terras a favor de latifundiários, impedindo a agricultura familiar e impondo a pecuária extensiva na região do Mearim”. (ANDRADE, 2007, p.24)

A descrição do que ocorreu nessa época, parece ter a sua reedição garantida no presente, quando assistimos a processos tão semelhantes que ocorrem em vários territórios rurais, inclusive nos Campos e Lagos. Andrade (2007, p.24) continua essa descrição dos processos de expulsão dos trabalhadores, afirmando:

Os latifundiários buscavam incorporar as áreas ocupadas pelos pequenos produtores de alimentos a suas grandes propriedades, adquirindo, daqueles agricultores que dispunham, pequenas ou médias quantidades de terra e expulsando as famílias ali estabelecidas. Introduziram a utilização das máquinas para avançar com as derrubadas (agora da floresta secundária, os babaçuais), arando a terra para plantar capim em grandes extensões.

Essa reprodução de cenários ao longo da história da Baixada Maranhense implica a necessidade de se compreender que essas situações refletem o modo como se desenvolve o capitalismo no estado do Maranhão, no Brasil e no mundo, considerando que realiza movimentos associados e complementares entre várias dimensões do circuito de produção, circulação e consumo, mediante estratégias de centralização e descentralização, concentração e desconcentração de capitais, de acordo com interesses e conveniências dos grandes empresários, latifundiários e banqueiros.

Mantidas as políticas de financiamento do agronegócio, dificilmente poderá se alterar, de modo substancial a situação dos trabalhadores e trabalhadoras, porque "a agricultura familiar não integrada nas cadeias do agronegócio, operam fora de uma estratégia tipicamente capitalista." (CARTER, 2010, p.95).

As análises das conjunturas dos diferentes períodos da história da Baixada Maranhense demonstraram a existência de elementos de caráter estrutural que permanecem no presente e que definem os limites reais para a superação das desigualdades existentes entre os diferentes segmentos da população urbana e rural do TR Campos e Lagos.

Há, portanto, que se fortalecer no âmbito dos territórios rurais a perspectiva de busca permanente de qualificação profissional, de fortalecimento das organizações locais para contribuírem no debate territorial, visando a continuidade da luta pela terra e pela renda, enfim pelo acesso a todos os bens materiais e não-materiais que, por direito, devem ser democratizados, garantindo a todos os cidadãos brasileiros, habitantes das cidades e do campo, condições de vida digna e de qualidade, como um processo coletivo de estruturação de outra sociedade.

O desafio é superar-se o precário estágio da necessidade e da auto reprodução dos trabalhadores brasileiros, sob os mínimos dos mínimos, para um real estágio de capacidades para a liberdade e o desenvolvimento. (IVO,2008, p.240).

Isso implica em lutar cotidianamente, no sentido de superar os limites que estão dados pelas políticas neoliberais que ainda definem o funcionamento de muitos setores de operação do Estado nacional, inclusive no que tange ao desenvolvimento da agricultura familiar e da educação destinada aos habitantes das áreas rurais. 
Essas constatações indicam, uma vez mais, que somente com a ação efetiva dos segmentos de trabalhadores e trabalhadoras do campo e na cidade poderá se realizar um avanço mais significativo em termos de garantia da realização de políticas públicas que são fundamentais e não podem continuar sendo adiadas. Modificar essa situação adversa é possível. Temos no próprio Estado do Maranhão o exemplo das quebradeiras de coco. Elas conseguiram alcançar uma liderança coletiva em processos de reivindicação, de realização de práticas de organização e em ocupação efetiva do espaço que precisa ser ocupado pela sociedade civil na luta pelas políticas públicas destinadas aos segmentos majoritariamente excluídos. Na atualidade, as quebradeiras participam da Comissão Nacional de Povos e Comunidades Tradicionais - CNPCT e conseguiram incluir o babaçu no Plano Nacional dos Produtos da Sócio- biodiversidade, coordenado pelos Ministérios do Desenvolvimento Agrário, do Meio Ambiente e do Desenvolvimento Social e pela Companhia Nacional de Abastecimento- CONAB. (Araújo, 2010, p.4)

Os trabalhadores e trabalhadoras do campo no TR Campos e Lagos estão progressivamente construindo seus caminhos e suas práticas, no sentido de alcançarem também a condição de sujeitos coletivos, com capacidade técnica e compromisso político de realizar a luta pelos seus direitos e, mais do que isso, a ação transformadora de caráter político e pedagógico que poderá imprimir à paisagem dos Campos e Lagos outro ritmo, outra temporalidade e territorialidade, num circuito virtuoso de superação de desigualdades sociais tão gritantes.

\section{6- Referências Bibliográficas}

ALMEIDA, Alfredo Wagner Berno de (org.) Economia do babaçu - levantamento preliminar de dados/Alfredo Wagner Berno de Almeida, Joaquim Shiraishi Neto, Benjamin Alvino de Mesquita (orgs). Helciane de Fátima Abreu Araújo, Cynthia Carvalho Martins, Miguel Henrique P. Silva. ${ }^{\text {a }}$ ed. São Luís, MIQCB/Balaios Typographia, 2001.

ALMEIDA, Alfredo Wagner Berno de. Os quilombolas e a base de lançamento de foguetes de Alcântara. Brasília, MMA, 2006.

ARAÚJO, Helciane de Fátima Abreu. Quebradeiras de coco babaçu. A resistência viva contra práticas de genocídio. São Luís, Vias de Fato. Jornalismo a serviço da causa popular, maio de 2010.

ARCANGELI, Alberto. O mito da terra: uma análise da colonização da pré-amazônia maranhense. São Luís, EDUFMA, 1987.

ASSELIN, Victor. Grilagem: corrupção e violência em terra de Carajás. Petrópolis:Vozes, 1982.

BRASIL/IBGE. Censo Agropecuário. Agricultura familiar . Brasília:IBGE, 2006

BRASIL, Ministério do Desenvolvimento Agrário - Gênero, agricultura familiar e reforma agrária no Mercosul. Brasília: Ministério do Desenvolvimento Agrário, 2006.

CABRAL, Maria Regina Martins \& ROSAR, Maria de Fatima Felix. Construindo com os jovens um novo ensino médio e educação profissional na região dos lagos- baixada maranhense. In Revista Pedagogia Cotidiano Ressignificado, no 1, Editora Central dos Livros, São Luis, 2005.

\& ROSAR, Maria de Fatima Felix (org.). Ensino Médio e Educação

Profissional no Maranhão. Editora Central dos Livros, São Luís, 2004.

(orgs). Projeto Jovem Cidadão. Editora Central dos Livros, São Luís, 2004.

CARTER, Miguel (org.) Combatendo a desigualdade social. O MST e a reforma agrária no Brasil. São Paulo: Editora UNESP, 2010.

Revista HISTEDBR On-line, Campinas, número especial, p. 5-27, out2011 - ISSN: 1676-2584 
CARVALHO, Alexandre Xavier Ywata; ALBUQUERQUE, Carlos Wagner; MOTA, José Aroudo; PIANCASTELLI, Marcelo. Dinâmica dos municípios. Brasília: IPEA, 2007.

CASTELAR, Armando \& SICSÚ, João. Sociedade e economia. Estratégias de crescimento e desenvolvimento. Brasília: IPEA, 2009.

IVO, Anete Brito Leal. Viver por um Fio: pobreza e política social. São Paulo: Annablume; Salvador: CRH/UFBA, 2008 (Trabalho e contemporaneidade).

LACROIX, Maria de Lourdes Lauande. A educação na baixada maranhense,1822-1589.São Luís:SECMA, 1982.

MAY, P.H. Palmeiras em chamas: transformação agrária e justiça social na zona babaçu.São Luís, EMAPA/FINEP/Fundação Ford, 1990.

MESQUITA, Benjamin. Alvino de. A crise da economia do babaçu no Maranhão (1920-80). Revista de Políticas Públicas, São Luís, v.2, n.2, p.61-76,jul/dez.1996.

A transformação da pecuária maranhense sob a ação governamental e as forças de mercado.: ritmo e rumos da ação do capital no período de 1970 a 2000. 2006. Tese (Doutorado). Universidade Federal do Maranhão - Université Paris III - Sorbonne Nouvelle, São Luís.

Luís, v.12, n.1, jan/jun, 2008

As nulheres agroextrativistas do babaçu. Revista de Políticas Públicas, São

PEREIRA JÚNIOR, Davi. Quilombos de Alcântara: território e conflito. O intrusamento do território das Comunidades Quilombolas de Alcântara pela empresa binacional Alcântara Cyclone Space. Manaus: Editora da Universidade Federal do Amazonas, 2009.

PERICO, Rafael Echeverry. Identidade e território no Brasil. Brasília: Instituto Interamericano de Cooperação para a Agricultura, 2009.

QUEIROZ, D.L.M. de. Viabilidade da utilização do carvão do coco de babaçu como alternativa energética para o parque guseiro da região de Carajás (versão preliminar) In: Relatório final do estudo sobre os complexos minero-metálicos na Amazônia Oriental: perspectivas e proposições de desenvolvimento regional. Projeto BRA/96/025-SUDAM/PNUD, Belém, 1999.

ROMANO, Jorge.O., ANDRADE, Maristela de Paula; ANTUNES, Marta. Olhar crítico sobre participação e cidadania : a construção de uma gocvernança democrática e participativa a partir do local. São Paulo: Expressão Popular: Action Aid Brasil, 2007.

SILVA, José de Ribamar Sá. Segurança alimentar, produção agrícola familiar e assentamentos de reforma agrária no Maranhão. São Luís:EDUFMA, 2008.

SPAVOREK, Gerd. (coord). A qualidade dos assentamentos da reforma agrária brasileira. São Paulo: Páginas e Letras, 2003. disponível em http://www.incra.gov.br

VEIGA, José Eli da. Cidades imaginárias:o Brasil é menos urbano do que se calcula.São Paulo:Autores Associados, 2002.

ZYLBERSZTAJN, Decio (coord). Reorganização do agronegócio do babaçu no Estado do Maranhão. Fundação Instituto de Administração; Faculdade de Economia, Administração e Contabilidade da USP, 2000.

Notas:

${ }^{1}$ Essa região começou a ser colonizada ainda no século XVII. A cidade de São Luis, capital do estado do Maranhão foi fundada em 1612. A capitania secundária de Cumã, que posteriormente deu origem ao

Revista HISTEDBR On-line, Campinas, número especial, p. 5-27, out2011 - ISSN: 1676-2584 26 
município de São Bento, tem documentos que revelam sua criação no ano de 1621. Alcântara foi criada em 1640 e a cidade de Viana, em 1757, Guimarãres, 1758. Vitória do Mearim, apesar de oficialmente ter sido criada em 1833, contava, desde o século XVII, com a presença de colonizadores que habitavam no que hoje constitui sua demarcação territorial.

${ }^{2}$ LACROIX, Maria de Lourdes Lauande. A educação na Baixada Maranhense: 1828-1889.São Luís: SECMA, 1982.

${ }^{3}$ THOMPSON, E.P. Costumes em Comum: Estudos sobre a cultura popular tradicional. São Paulo: Companhia das Letras, 1998, p.86-149.

${ }^{4}$ A Constituição Brasileira definiu o processo de reconhecimento de terras produtivas e improdutivas, permitindo a elaboração de leis ordinárias que adotam os seguintes fundamentos de ordem jurídica, mas, principalmente, de caráter social, para avaliar a condição real de seu aproveitamento. Para melhor explicitar $o$ que estamos defendendo poderíamos adotar a seguinte equação: $P P=E E+E R$, onde PP=Propriedade Produtiva, EE - Exploração Econômica e ER - Exploração Racional, sendo que EE $=G U T+G E E$ e ER $=$ $F A+F T+F B E$, ou seja, função ambiental + função trabalhista + função bem estar, ficando assim a equação final: $P P=(G U T+G E E)+(F A+F T+F B E)$. Isso evidenciaria o que a ordem positivada já expressa e o que este parecer visa proclamar: Que no conceito de função social está contido o conceito de produtividade, mas que no conceito de produtividade também estão contidas parcelas dos conceitos de função ambiental, função trabalhista e função bem estar, isto é, que a função social é continente e conteúdo da produtividade. Pinto Júnior, Joaquim Modesto, Farias, Valdez Adriani. Função social da propriedade: dimensões ambiental e trabalhista. - Brasília: Núcleo de Estudos Agrários e Desenvolvimento Rural, 2005.

Recebido em: $\quad$ 25/07/2011

Aprovado em: $\quad 01 / 08 / 2011$ 